\title{
KEBUGARAN JASMANI PADA MAHASISWA OBESITAS POLTEKKES KEMENKES TASIKMALAYA
}

\section{JASMANI FITNESS IN OBESITY STUDENTS OF POLTEKKES KEMENKES TASIKMALAYA}

\author{
Dewi Aryanti ${ }^{1}$, Tritania Ambarwati ${ }^{2 *}$ \\ ${ }^{1}$ Program Studi D III Keperawatan Poltekkes Kemenkes Tasikmalaya \\ ${ }^{2}$ Program Studi D III Kesehatan Gigi Poltekkes Kemenkes Tasikmalaya \\ *drgtritania@gmail.com
}

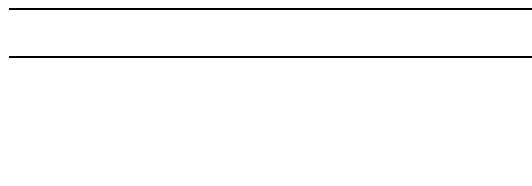

ABSTRAK

Kata kunci:

Kebugaran Fisik, Obesitas, Siswa

Latar belakang: Kebugaran fisik adalah masalah penting bagi setiap individu termasuk siswa. Kebugaran fisik berkaitan erat dengan kondisi obesitas dan tingkat aktivitas fisik. Beberapa siswa Poltekkes Kemenkes Tasikmalaya memiliki kondisi obesitas dan aktivitas fisik yang rendah. Tujuan dari penelitian ini adalah untuk mendapatkan gambaran kebugaran jasmani pada siswa obesitas di Politeknik Kementerian Kesehatan Tasikmalaya. Metode: Penelitian ini menggunakan desain deskriptif noneksperimental. Total sampel subjek dalam penelitian ini adalah 100 siswa reguler (75 perempuan dan 25 laki-laki) yang telah diskrining untuk obesitas dengan indeks massa tubuh (IMT)> 24,9. Setelah mengisi data demografi dan antropometrik umum, sampel kemudian menjalani pengukuran kebugaran fisik menggunakan teknik Balke. Data dianalisis menggunakan nilai kecenderungan pusat, proporsi / persentase untuk variabel tingkat kebugaran fisik, Hasil penelitian ini menunjukkan bahwa $100 \%$ siswa obesitas di Politeknik Kementerian Kesehatan Tasikmalaya memiliki tingkat kebugaran fisik yang sangat rendah. Kondisi ini membutuhkan dukungan dan perhatian individu yang relevan dan Poltekkes Kementerian Kesehatan dari Kementerian Kesehatan Tasikmalaya untuk mencegah risiko yang lebih parah.

Key word:

Physical Fitness, Obesity, Students

\section{ABSTRACT}

Background: Physical fitness is an important issue for every individual including students. Physical fitness is closely related to the condition of obesity and the level of physical activity. Some Poltekkes Kemenkes Tasikmalaya students have conditions of obesity and low physical activity. The purpose of this study is to get a description of physical fitness in obese students in the Polytechnic of the Ministry of Health Tasikmalaya. Method: This study used a descriptive non-experimental design. The total sample of subjects in this study were 100 regular students (75 female and 25 male) who had been screened for obesity with a body mass index $(\mathrm{BMI})>24.9$. After filling in general demographic and anthropometric data, the sample then underwent physical 
fitness measurements using the Balke technique. Data were analyzed using central tendency values, proportions / percentages for physical fitness level variables; Results: The results of this study showed that $100 \%$ of obese students in the Poltekkes of the Ministry of Health Tasikmalaya had a very low level of physical fitness. This condition requires the support and attention of relevant individuals and the Poltekkes Ministry of Health of the Ministry of Health Tasikmalaya to prevent more severe risks.

\section{PENDAHULUAN}

Kebugaran jasmani adalah salah satu aspek penting dalam kehidupan setiap individu. Beberapa individu memiliki risiko kesehatan yang mengancam kehidupan jika kebugaran jasmani berada pada tingkat yang rendah. Risiko ini mungkin saja diperberat dengan kondisi patologis lainnya, seperti obesitas. ${ }^{(1)}$

Obesitas secara umum disebabkan karena adanya penggunaan energi tidak seimbang dengan energi yang didapatkan. Kondisi ini menyebabkan peningkatan jumlah lemak tubuh dan terjadilah obesitas. Salah satu penyebab kelebihan energi adalah rendahnya tingkat aktivitas fisik. ${ }^{(1)}$

Aktivitas fisik merupakan salah satu bagian penting dalam pola hidup sehat. Banyak gangguan kesehatan yang muncul akibat aktivitas fisik yang kurang, seperti stroke, diabetes mellitus dan penyakit tidak menular lainnya. ${ }^{(2)}$. Saat ini, Indonesia tengah mengalami perubahan pola penyakit yang sering disebut transisi epidemiologi. Hal ini ditandai dengan meningkatnya kematian dan kesakitan akibat penyakit tidak menular (PTM). Selain berkaitan dengan masalah PTM, kurangnya aktivitas fisik juga berpengaruh terhadap tingkat kebugaran jasmani. ${ }^{(3)}$

Kebugaran jasmani berpengaruh positif terhadap seluruh system organ tubuh. Pada system saraf, proses angiogenesis dan sinaptogenesis berfungsi sangat baik. Selain itu, kebugaran jasmani yang baik dapat meningkatkan suatu protein factor yang menghasilkan plastisitas jaringan otak, yaitu brain-derived neurothropic factor (BDNF). Protein ini terdapat pada sel saraf pusat dan perifer. Pada otak, protein BDNF banyak terdapat pada area hippocampus dan hipotalamus Hal ini diikuti dengan peningkatan kemampuan kognitif, yaitu berkonsentrasi, dan memori. ${ }^{(4)}$

Kemampuan kognitif yang baik sangat dibutuhkan oleh mahasiswa dalam proses belajar baik bentuk pembelajaran teori, praktikum bahkan praktik kerja lapangan (PKL). Bentuk PKL pada mahasiswa di perguruan tinggi kesehatan yang sangat spesifik diantaranya adalah pembelajaran klinik. Pembelajaran klinik mengharuskan mahasiswa praktik secara langsung di tempat pelayanan kesehatan berikut dengan sejumah resikonya. Resiko ini meliputi paparan penyakit menular, dinas dengan metode shift dan kelelahan fisik serta mental. Kondisi ini menuntut mahasiswa untuk memiliki kebugaran jasmani yang baik agar dapat mengendalikan sejumlah resiko. Untuk dapat memiliki kebugaran jasmani yang baik maka dibutuhkan keteraturan latihan fisik (exercise) yang teratur dan aktivitas fisik yang baik. Sejumlah studi menunjukkan bahwa aktivitas fisik memiliki korelasi positif dengan tingkat kebugaran jasmani. ${ }^{(5)(6)}$

Meskipun demikian, berdasarkan pengamatan lapangan di Poltekkes Tasikmalaya, banyak mahasiswa yang yang lebih sering menggunakan kendaraan motor untuk mencapai jarak tempuh kurang dari 200 meter dan penggunaan waktu istirahat yang mayoritas digunakan untuk mengakses media social dan game offlinelonline dengan duduk di kelas. 
Selain itu, aktivitas fisik lain mahasiswa di kampus diantaranya adalah praktikum di laboratorium. Aktivitas ini tergolong aktivitas fisik ringan dan sedang.

Kemudian, di setiap jurusan tidak terdapat mata ajaran olah raga yang sangat menunjang terhadap kebugaran jasmani. Terdapat kegiatan olah raga di luar waktu pembelajaran, seperti futsal, basket dan bela diri namun hanya sebagian kecil mahasiswa yang konsisten mengikutinya. Secara umum, kondisi inaktivitas fisik mendominasi waktu selama di kampus. Kondisi ini menjadi indikasi rendahnya tingkat aktivitas fisik yang memungkinkan rendah pula tingkat kebugaran jasmani pada mahasiswa Poltekkes Kemenkes Tasikmalaya. Berdasarkan hal di atas, penelitian dilaksanakan untuk mengetahui gambaran tingkat kebugaran jasmani mahasiswa Poltekkes Kemenkes Tasikmalaya, khususnya pada kelompok mahasiswa obesitas.

Data Riset Kesehatan Dasar tahun 2013 menginformasikan bahwa 80 \% masyarakat Indonesia mengalami masalah dengan kesehatan gigi dan mulutnya, terutama yang berkaitan dengan karies gigi dan penyakit jaringan penyangga gigi (Laporan Riskesdas, 2013). Hal ini terkait banyak faktor diantaranya pengetahuan, perilaku dan kebiasaan konsumsi makanan. Salah satu efek dari konsumsi makanan adalah hal yang berkaitan dengan pewarnaan pada gigi. Pewarnaan gigi adalah suatu perubahan warna pada gigi, yang dapat disebabkan oleh faktor eksternal (luar), internal (dalam) atau kedua-duanya. Perubahan warna gigi menjadi masalah karena membuat banyak orang merasa tidak nyaman ketika berbicara atau tersenyum, karena mereka berkeyakinan bahwa gigi putih mampu membuat orang merasa lebih percaya diri (Hendari, 2009). Penelitian terkait dilakukan Sopianah dan Kristiani (2015) yang menyimpulkan bahwa perubahan warna pada gigi dapat memberikan dampak psikologis.

Perubahan warna gigi selain dapat menyebabkan masalah pada faktor estetika juga merupakan faktor resiko terjadinya penyakit gigi dan mulut yang disebabkan oleh plak, diantaranya karies dan penyakit jaringan periodontal. Berdasarkan penyebabnya, pewarnaan pada gigi (stain) dibagi menjadi dua, yaitu pewarnaan intrinsik dan pewarnaan ekstrinsik. Pewarnaan intrinsik merupakan pewarnaan yang berada didalam permukaan gigi yang dapat disebabkan oleh antibiotik tetrasiklin, fluorosis gigi, dan proses penuaan. Pewarnaan intrinsik menyebabkan perubahan warna pada bagian dalam struktur gigi atau dentin selama masa pertumbuhan gigi. Proses penghilangan pewarnaan intrinsik relatif sulit dan membutuhkan metode-metode khusus seperti bleaching (Anggraeni, 2014).

Pewarnaan ekstrinsik adalah pewarnaan yang terdapat pada permukaan gigi akibat pewarnaan pelikel. Pewarnaan ekstrinsik biasanya disebabkan oleh konsumsi minuman berwarna, merokok dan penggunaan obat-obatan tertentu. Salah satu minuman berwarna yang dapat menyebabkan pewarnaan ekstrinsik adalah teh. Meminum teh sudah menjadi kebiasaan dan budaya bagi penduduk dunia. Rata-rata konsumsi teh penduduk dunia adalah $120 \mathrm{ml} /$ hari per kapita. Jika konsumsi teh dilakukan secara rutin, zat warna dalam teh akan terdeposit pada plak dan lapisan biofilm pada permukaan email yang dapat menyebabkan perubahan warna pada gigi (Anggraeni, 2014).

Teh merupakan hasil pengolahan pucuk (daun muda) dari tanaman teh (camelia sinensis) yang dipakai sebagai bahan minuman. Berbagai legenda asal mula teh yang terpopuler adalah legenda Kaisar Shen Nung dari provinsi Yunan Cina pada tahun 2737 SM, yaitu ketika sedang memasak seduhan minumnya, dengan tidak sengaja sehelai daun yang berasal dari ranting kering yang dipakainya sebagai kayu bakar, terbang dan tercelup kedalam ketel seduhan. Seduhan seduhan daun tersebut kemudian menghasilkan sebuah 
minuman baru yang beraroma khas yang hingga kini dikenal sebagai teh (Kurniawan, 2011).

Tanaman teh (camelia sinensis) banyak ditanam diberbagai negara di dunia sejak zaman dulu termasuk Indonesia. Teh dapat tumbuh dengan baik di daerah pegunungan beriklim sejuk pada ketinggian 1800 meter diatas permukaan laut (Renyaan, 2005). Tanaman teh diperkenalkan di Indonesia pada tahun 1686 oleh seorang ahli botanical sekaligus dokter dari Belanda bernama Andreas Cleyer di perkebunan Batavia. Negara Indonesia pernah berjaya sebagai salah satu produsen teh besar di dunia. Indonesia banyak memiliki perkebunan teh di Jawa dan Sumatera, tetapi sekarang ini hasil produksi terus mengalami kemunduran (Rossi, 2010).

Salah satu kandungan teh hijau adalah katekin yang bersifat anti mikroba dan dapat menghambat pertumbuhan Streptococcus mutans yakni bakteri yang dapat menyebabkan karies gigi (Christiany, 2008). Selain kandungan yang memberikan efek yang baik bagi kesehatan gigi, tetapi perlu diingat juga bahwa kandungan Chromogen dan tannin atau pigmen pada teh juga mudah menempel pada gigi sehingga dapat menimbulkan pewarnaan ekstrinsik pada gigi (Hafsanir, 2011). Pewarnaan ekstrinsik secara tekstur merupakan tempat akumulasi sisa makanan dan plak yang dapat menimbulkan penyakit gigi dan jaringan penyangganya. Minum teh adalah merupakan suatu kebiasaan yang turun temurun dari generasi ke generasi di masyarakat, khususnya di masyarakat desa Sindangkasi Kecamatan Purbaratu Kota Tasikmalaya. Jenis teh yang dikonsumsi masyarakat ada bermacam-macam, tetapi yang terbanyak adalah teh hijau. Berdasarkan uraian di atas, maka penulis tertarik untuk mengangkat judul "Hubungan Konsumsi Seduhan Teh Hijau dengan Pewarnaan Ekstrinsik Gigi pada Kelompok Tani Desa Sindangkasih Kecamatan Purbaratu Kota Tasikmalaya"

\section{METODE}

Desain penelitian ini adalah non eksperiment dengan jenis deskriptif. Populasi pada penelitian ini adalah seluruh mahasiswa tingkat 1, 2 dan 3 Prodi D3 di Poltekkes Kemenkes Tasikmalaya, wilayah Tasikmalaya kelas Reguler yang dilakukan screening terhadap kondisi berat badan obesitas, yaitu individu yang memiliki indeks massa tubuh (IMT) >24,9. Sampel penelitian ini sama dengan populasi yang dihasilkan screening obesitas, yang berjumlah 100 orang. Instrumen yang akan digunakan pada penelitian ini adalah daftar isian identitas yang mencakup usia, jenis kelamin, tinggi badan, berat badan, kebiasaan merokok;.Selain itu, instrumen lainnya yang digunakan untuk mengukur tingkat kebugaran jasmani adalah Formulasi Balke yang membutuhkan stopwatch dan lintasan lari sepajang 400 meter. Analisis Data univariat menggunakan nilai tendensi sentral, proporsi/persentase untuk variabel tingkat kebugaran fisik.

\section{HASIL DAN PEMBAHASAN}

1. Jenis Kelamin

Tabel 1. Distribusi Responden Menurut Jenis Kelamin pada Mahasiswa Poltekkes Kemenkes Tasikmalaya tahun 2018

\begin{tabular}{ccc}
\hline Jenis Kelamin & Jumlah & Persentase (\%) \\
\hline Laki-laki & 25 & 25,0 \\
Perempuan & 75 & 75,0 \\
Jumlah & 100 & 100,0
\end{tabular}

Berdasarkan data pada table 1, maka sebagian besar (75\%) responden berjenis kelamin perempuan. 
2. Usia, Berat Badan, Tinggi Badan, dan Indeks Massa Tubuh

Tabel 2. Distribusi Responden Menurut Usia, Berat Badan, Tinggi Badan, dan Indeks Massa Tubuh pada Mahasiswa Poltekkes

KemenkesTasikmalaya tahun 2018

\begin{tabular}{lllll}
\hline Variabel & Mean & Standar Deviasi & $\begin{array}{l}\text { Minimal - } \\
\text { Maksimal }\end{array}$ & $\begin{array}{l}\text { Confident } \\
\text { Interval 95\% }\end{array}$ \\
\hline Usia & 18,90 & 0,937 & $17-21$ & $18,71-19,09$ \\
Berat Badan $(\mathrm{Kg})$ & 73,96 & 11,89 & $58,5-119,0$ & $71,59-76,32$ \\
Tinggi Badan $(\mathrm{cm})$ & 159 & 6,79 & $146,8-176$ & $157,66-160,35$ \\
Indeks massa tubuh & 29,19 & 3,79 & $25-42,2$ & $28,4-29,9$ \\
$(\mathrm{IMT})\left(\mathrm{kg} / \mathrm{m}^{2}\right)$ & & & & \\
\hline
\end{tabular}

Berdasarkan data pada tabel 2 , maka rerata usia responden adalah 18,9 tahun dengan standar deviasi 0,93 tahun. Usia termuda adalah 17 tahun dan tertua adalah 21 tahun. Pada variabel berat badan, rerata berat badan responden adalah $73,96 \mathrm{~kg}$ dengan standar deviasi sebesar 11, $89 \mathrm{~kg}$. Selanjutnya, variabel tinggi badan memiliki rerata 159 $\mathrm{cm}$ dengan standar deviasi $6,79 \mathrm{~cm}$. Variabel IMT memiliki rerata $29,19 \mathrm{~kg} / \mathrm{m}^{2}$ dan standar deviasi $3,79 \mathrm{~kg} / \mathrm{m}^{2}$. Data pada variabel di tabel 4.2 diyakini $95 \%$ memiliki rentang usia 18,7-19,1 tahun.

3. Kebiasaan Merokok dan Obesitas

Tabel 3. Distribusi Responden Menurut Kebiasaan Merokok dan Tingkatan Obesitas pada Mahasiswa Poltekkes Kemenkes Tasikmalaya tahun 2018

\begin{tabular}{ccc}
\hline Variable & Jumlah & Persentase (\%) \\
\hline Kebiasaan Merokok & 5 & 5,0 \\
Ya & 95 & 95,0 \\
Tidak & 100 & 100,0 \\
Jumlah & & \\
Tingkatan Obesitas & 64 & 64,0 \\
Obesitas 1 & 36 & 36,0 \\
Obesitas 2 & 100 & 100,0 \\
Jumlah &
\end{tabular}

Berdasarkan data pada table 3, sebagian besar responden tidak merokok. Selain itu, sebagian besar responden tergolong pada tingkat obesitas 1 . Tingkatan ini memiliki risiko morbiditas yang moderate (sedang)

4. Kebiasaan Merokok Berdasarkan Tingkatan Obesitas

Tabel 4. Distribusi Responden Menurut Kebiasaan Merokok berdasarkan Tingkatan Obesitas pada Mahasiswa Poltekkes Kemenkes Tasikmalaya tahun 2018

\begin{tabular}{ccccc}
\hline Tingkatan Obesitas & \multicolumn{2}{c}{ Kebiasaan Merokok } & Jumlah & Persentase \\
& Ya & Tidak & & \\
\hline Obesitas 1 & 2 & 62 & 64 & 64,0 \\
Obesitas 2 & 3 & 33 & 36 & 36,0 \\
Jumlah & 5 & 95 & 100 & 100,0 \\
\hline Berdasarkan data pada tabel 4 maka hanya sebagian kecil dari kelompok obesitas 1
\end{tabular}
dan obesitas 2 yang memiliki kebiasaan merokok. 
5. Tingkatan Obesitas Berdasarkan Jenis Kelamin

Tabel 5. Distribusi Responden Menurut Tingkat Obesitas berdasarkan Jenis Kelamin pada Mahasiswa Poltekkes Kemenkes Tasikmalaya tahun 2018

\begin{tabular}{ccccc}
\hline Tingkatan Obesitas & \multicolumn{2}{c}{ Jenis Kelamin } & Jumlah & Persentase \\
& Laki-laki & Perempuan & & \\
\hline Obesitas 1 & 9 & 55 & 64 & 64,0 \\
Obesitas 2 & 16 & 20 & 36 & 36,0 \\
Jumlah & 25 & 75 & 100 & 100,0 \\
\hline
\end{tabular}

Berdasarkan data pada tabel 5 maka hanya sebagian besar kelompok obes 2 berjenis kelamin perempuan.

6. Tingkat Kebugaran Jasmani

Tabel 6. Distribusi Responden Menurut Tingkat Kebugaran Jasmani pada Mahasiswa Poltekkes Kemenkes Tasikmalaya tahun 2018

\begin{tabular}{ccc}
\hline Tingkat Kebugaran Jasmani & Jumlah & Persentase (\%) \\
\hline Baik sekali & 0 & 0,0 \\
Baik & 0 & 0,0 \\
Sedang & 0 & 0,0 \\
Kurang & 0 & 0,0 \\
Kurang sekali & 100 & 100,0 \\
Jumlah & 100 & 100,0 \\
\hline
\end{tabular}

Berdasarkan data pada tabel 5.5, tingkat kebugaran jasmani seluruh responden berada pada tingkat kurang sekali. Kategori ini merupakan tingkat kebugaran jasmani terendah. Hasil penelitian menunjukkan bahwa seluruh responden memiliki tingkat kebugaran jasmani yang kurang sekali (KS). Kondisi ini sangat ditunjang dengan kondisi obesitas pada responden. Bahkan, sebagian kecil responden tergolong pada kelompok obesitas 2 yang memiliki tingkat resiko morbiditas yang berat.

Pengukuran obesitas dalam penelitian ini menggunakan formulasi indeks massa tubuh (IMT). Indeks massa tubuh direkomendasikan oleh World Health Organization untuk mengukur tingkat obesitas pada individu dewasa. Seluruh responden memiliki indeks masa tubuh lebih dari 25. World Health Organization mengelompokkannya ke dalam katagori obesitas 1 dan $2 .{ }^{(1)}$ Kedua kelompok ini memiliki risiko morbiditas sedangberat. Risiko morbiditas terutama terkait dengan penyakit kardiovaskular, diabetes tipe 2, kanker gastrointestinal, batu empedu. Selain itu, kondisi obesitas meningkatkan risiko mortalitas sebesar 1,9 kali di bandingkan dengan kelompok dengan IMT dalam batas normal $(18,5-22,9) .^{(1)(7)}$

Tingkat morbiditas pada obesitas berbeda antara laki-laki dan perempuan di Asia. Perempuan memiliki tingkat resiko morbiditas sebesar 2,4 kali lipat dibandingkan kelompok dengan IMT normal. Pada laki-laki, resiko sedikit lebih rendah, yaitu 2,2 kali lipat dibandingkan dengan kelompok dengan IMT normal. ${ }^{(1)}$ Resiko morbiditas dapat meningkat jika disertai dengan faktor lain, seperti kebiasaan merokok. Sebagian kecil responden $(5 \%)$ mengaku memiliki kebiasaan merokok. Individu dewasa dengan obesitas perokok memiliki harapan hidup 13 tahun lebih pendek dibandingkan dengan individu dewasa obesitas yang bukan perokok. Akan tetapi, banyak diyakini oleh individu dengan obesitas menyatakan bahwa dengan merokok maka nafsu makan akan berkurang. ${ }^{(8)}$ Keyakinan ini dibantah oleh penelitian Dare et al., yang menyatakan bahwa tidak ada perbedaan yang signifikan antara risiko obesitas baik pada perokok maupun bukan perokok. Meskipun demikian, secara umum terdapat beberapa studi yang telah membuktikan kebiasaan merokok membawa banyak kerugian kesehatan dan sangat tidak direkomendasikan untuk dikonsumsi. ${ }^{(9)}$ 
Resiko morbiditas dan mortalitas pun semakin meningkat apabila tingkat kebugaran jasmani aerobik sangat kurang. Wessel et al. menyebutkan bahwa pada wanita tidak ada hubungan yang independen dan signifikan antara kondisi obesitas dan penyakit jantung koroner. Akan tetapi, ada faktor lain yang lebih berhubungan erat secara independen dengan penyakit itu. Faktor ini adalah faktor kebugaran jasmani ${ }^{(10)}$. Selain itu, Ekelund et.al., dan Wei et al., menambahkan bahwa kebugaran jasmani aerobik pada laki-laki pun merupakan prediktor mortalitas penyakit kardiovaskular. Wei et al., bahkan membandingkannya dengan risiko mortalitas penyakit kardiovaskular lainnya, seperti diabetes melitus dan lain-lain. Kebugaran jasmani aerobik merupakan prediktor paling independen dibanding yang lainnya. ${ }^{(11)(12)}$

\section{KESIMPULAN}

Dari pembahasan di atas, kebugaran jasmani terutama kebugaran aerobik sangat dibutuhkan oleh semua individu tidak terkecuali mahasiswa. Mahasiswa Poltekkes Kemenkes Tasikmalaya memiliki aktivitas pembelajaran dengan tantangan jasmani yang cukup berat. Pembelajaran teori dan prraktikum di laboratorium serta praktik klinik di lapangan (rumah sakit). Rumah sakit merupakan lahan praktik yang memiliki risiko tinggi menularkan penyakit infeksi. Selain itu, pada mahasiswa jurusan keperawatan dan kebidanan dituntut menyesuaikan diri terhadap jadual dinas pagi, sore dan malam. Secara fisiologis, tentunya irama sirkadian tubuh akan mengalami perubahan

\section{DAFTAR PUSTAKA}

1. World Health Organizations (WHO). Redefining Obesity and It's Treatment. Geneva, Switzerland: World Health Organization. 2000.

2. RI [KEMENKES] Kementrian Kesehatan. Riset Kesehatan Dasar (RISKESDAS) 2013. Laporan Nasional 2013. 2013.

3. Kemenkes RI. Petunjuk Teknis Pos Pembinaan Terpadu Penyakit Tidak Menular (Posbindu PTM). Ditjen Pengendali Penyakit dan Penyehatan Lingkungan, Kementeri Kesehat RI. 2012;

4. Esteban-Cornejo I, Tejero-Gonzalez CM, Sallis JF, Veiga OL. Physical activity and cognition in adolescents: A systematic review. Journal of Science and Medicine in Sport. 2015.

5. Lepp A, Barkley JE, Sanders GJ, Rebold M, Gates P. The relationship between cell phone use, physical and sedentary activity, and cardiorespiratory fitness in a sample of U.S. college students. Int J Behav Nutr Phys Act. 2013;

6. McKinney J, Lithwick DJ, Morrison BN, Nazzari H, Isserow SH, Heilbron B, et al. The health benefits of physical activity and cardiorespiratory fitness. B C Med J. 2016;

7. Forbes A. Human Nutrition and Dietetics. Postgrad Med J. 1994;

8. Dare S, Mackay DF, Pell JP. Relationship between smoking and obesity: A crosssectional study of 499,504 middle-aged adults in the UK general population. PLoS One. 2015;

9. Peeters A, Barendregt JJ, Willekens F, Mackenbach JP, Al Mamun A, Bonneux L, et al. Obesity in adulthood and its consequences for life expectancy: A life-table analysis. Ann Intern Med. 2003;

10. Wessel TR, Arant CB, Olson MB, Johnson BD, Reis SE, Sharaf BL, et al. Relationship of physical fitness vs body mass index with coronary artery disease and cardiovascular events in women. J Am Med Assoc. 2004; 
11. Ekelund LG, Haskell WL, Johnson JL, Whaley FS, Criqui MH, Sheps DS. Physical fitness as a predictor of cardiovascular mortality in asymptomatic North American men. The Lipid Research Clinics Mortality Follow-up Study. N Engl J Med. 1988;

12. Chen W, Srinivasan SR, Elkasabany A, Berenson GS. Cardiovascular risk factors clustering features of insulin resistance syndrome (Syndrome X) in a biracial (Black-White) population of children, adolescents, and young adults: The Bogalusa Heart Study. Am J Epidemiol. 1999; 